\title{
Taguchi Design of Internal Stress and Friction Measurements during Electrodeposition
}

Ebru Saraloglu Güler ${ }^{1 *}$ and Ishak Karakaya ${ }^{2}$

${ }^{1}$ Department of Mechanical Engineering, Başkent University, Ankara, Turkey

${ }^{2}$ Department of Metallurgical and Materials Engineering, Middle East Technical University, Turkey

\begin{abstract}
The electroplating method is a promising alternative to produce composite plating by using dispersed fine particles in the metal plating bath. The process can be either called electro-deposition or composite deposition. The particles are trapped in the deposit during the process. Internal stress is a common problem in plated deposits that affect the performance of the coatings and may even result in adhesion problems. Hence, the amount and type (compressive or tensile) of the internal stress must be controlled. $\mathrm{MoS}_{2}$ particle - nickel coatings can be referred as self-lubricating coatings that satisfy the demand for decreased friction in severe applications. The internal stress during $\mathrm{MoS}_{2}$ particle - nickel electro-deposition was measured by deposit stress analyzer. The effects of electroplating parameters that are $\mathrm{MoS}_{2}$ particle concentration, temperature and coating thickness on the internal stress values were investigated by Taguchi design. It is found that increasing $\mathrm{MoS}_{2}$ particle concentration and coating thickness led to decrease in the internal stress developed during $\mathrm{MoS}_{2}$-nickel composite coatings. Interaction effects of these parameters were also revealed.
\end{abstract}

Keywords: Electro-deposition; Lubrication; Tensile

\section{Introduction}

Internal stress is one of the major problems encountered during deposition that can lead to detachment of the coating [1]. The deposit contracts or expands respect to the substrate due to the type of the stress that can be either tensile (contraction) or compressive (expansion) and denoted by + and - respectively [2]. The stress that is in the range of $30 \mathrm{MPa}$ in electrodeposits up to $100 \mu \mathrm{m}$ thickness can be considered as acceptable [3]. It was concluded that increasing the temperature decreased the internal stress $[4,5]$. The combination of parameters that produce minimum internal stress during $\mathrm{Ni}-\mathrm{MoS}_{2}$ electro-co- deposition was investigated in this study. Since $\mathrm{MoS}_{2}$ has a self-lubricating property the deposition has the advantage of friction and high temperature applications. Therefore, it is critical to obtain stress free deposits or coatings with minimum stress level.

Taguchi design from Minitab was used to evaluate the influence of parameters and the interactions of these parameters during the experiments. Interaction parameter is important to observe the change of the response value by a specific parameter when the other parameter is high or low.

The easier and sufficiently precise measurement of internal stress can be done by the bent strip method. Two legged copper strips of $0.0508 \mathrm{~mm}$ thickness are immersed in the plating tank during bent strip testing method. Only one side of the strip is let to be plated by insulating the other side of the legs of the strips before deposition (Stein, 1996). Stress calculation is given as [2]:

$$
\begin{aligned}
& \mathrm{t}=\frac{\Delta \mathrm{m}}{\mathrm{D} \times \mathrm{A} \times 2.54} \\
& \mathrm{~S}=\frac{\mathrm{U} \times \mathrm{K}}{3 \times \mathrm{t}}
\end{aligned}
$$

Where; t: thickness of deposit (inch), $\Delta \mathrm{m}$ : weight gain (gram), D: density of nickel $\left(\mathrm{g} / \mathrm{cm}^{3}\right)$, A: area $\left(\mathrm{cm}^{2}\right)$, S: stress (psi), U: number of increments, K: strip constant ( $\mathrm{psi} \times$ inch).

\section{Experimental Section}

The Watts bath containing $300 \mathrm{~g} / \mathrm{L} \mathrm{NiSO}_{4} \cdot 6 \mathrm{H}_{2} \mathrm{O}$ (63035981; Umicore, Belgium), $50 \mathrm{~g} / \mathrm{L} \mathrm{NiCl}_{2} .6 \mathrm{H}_{2} \mathrm{O}$ (7791-20-0; Selnic, France), and $40 \mathrm{~g} / \mathrm{L}$ boric acid (minimum\% $99.9 \mathrm{H}_{3} \mathrm{BO}_{3}$, Etibank, Turkey) was prepared for the study. Following the bath preparation, the $\mathrm{MoS}_{2}$ particles with $1.440 \mu \mathrm{m}$ are incorporated. Incorporation process involves 5 hours agitation of the particles in $50 \mathrm{ml}$ Watts's solution to make slurry and 1 hour agitation following the completion up to the desired volume [6]. Nickel anode $(5 \times 5 \mathrm{~cm})$ was used. Copper alloy-194 bent strips received from Specialty Testing and Development Co. with a constant, $\mathrm{K}$, of 0.3449 ( $\mathrm{psi} \times$ inch) were used as the cathode

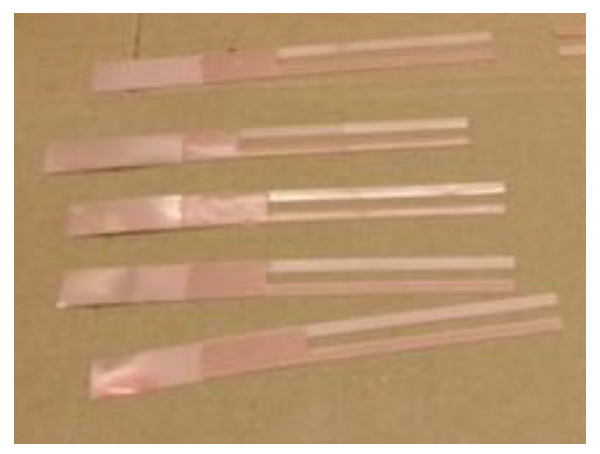

Figure 1: Copper strips having strip constant of 0.3449 with one side of the legs varnished.

*Corresponding author: Ebru Saraloglu Güler, Assistant Professor, Department of Mechanical Engineering, Başkent University, Ankara, Turkey, Tel: +90 312246 6666-2098; E-mail: esguler@baskent.edu.tr

Received July 05, 2017; Accepted July 12, 2017; Published July 22, 2017

Citation: Güler ES, Karakaya I (2017) Taguchi Design of Internal Stress and Friction Measurements during Electrodeposition. J Material Sci Eng 6: 353. doi: 10.4172/2169-0022.1000353

Copyright: $\odot 2017$ Güler ES, et al. This is an open-access article distributed under the terms of the Creative Commons Attribution License, which permits unrestricted use, distribution, and reproduction in any medium, provided the original author and source are credited. 
Citation: Güler ES, Karakaya I (2017) Taguchi Design of Internal Stress and Friction Measurements during Electrodeposition. J Material Sci Eng 6: 353. doi: 10.4172/2169-0022.1000353

Page 2 of 3

(Figure 1) that were cleaned by alkaline immersion treatment before plating. Schematic drawing of the electroplating cell with nickel anode and copper strip is showed in Figure 2.

The electroplating parameters were set as $\mathrm{MoS}_{2}$ particle concentration $(10$ and $30 \mathrm{~g} / \mathrm{l})$, temperature $\left(30\right.$ and $\left.50^{\circ} \mathrm{C}\right)$ and coating thickness $(25$ and $50 \mu \mathrm{m})$ with two levels. Internal stress will be the response value for Taguchi design given in Table 1. Two levels were designated by 1 and 2 for low and high values of each parameter respectively.

\section{Results and Discussion}

The internal stress values were measured for each experiment by bent strip method showed in Figure 3 and listed in Table 2 as the response value. The change in the internal stress with $\mathrm{MoS}_{2}$ concentration, temperature and coating thickness is showed graphically in Figure 4. Increase in $\mathrm{MoS}_{2}$ concentration and coating thickness decreased the internal stress whereas increasing temperature led to a slight increase in the internal stress. The result is consistent with the claim of Chou et al.

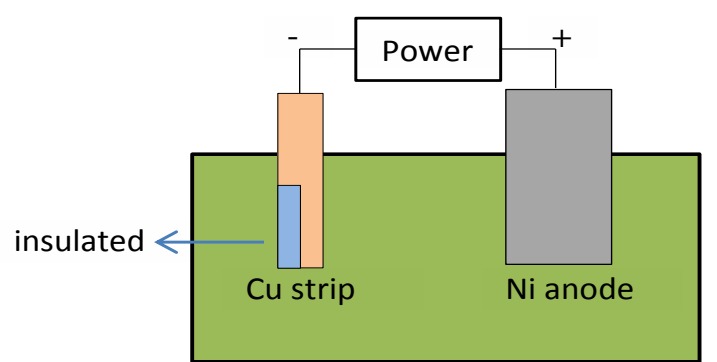

Figure 2: Schematic drawing of the cell showing nickel anode and Cu strip with one leg insulated cathode in watts bath.

\begin{tabular}{|c|c|c|c|}
\hline Experiment No & $\mathbf{M o S}_{\mathbf{2}}(\mathbf{g} / \mathbf{l})$ & Temperature $\left.\mathbf{~}^{\circ} \mathbf{C}\right)$ & Thickness $(\boldsymbol{\mu m})$ \\
\hline 1 & 1 & 1 & 1 \\
\hline 2 & 1 & 1 & 2 \\
\hline 3 & 1 & 2 & 1 \\
\hline 4 & 1 & 2 & 2 \\
\hline 5 & 2 & 1 & 1 \\
\hline 6 & 2 & 1 & 2 \\
\hline 7 & 2 & 2 & 1 \\
\hline 8 & 2 & 2 & 2 \\
\hline
\end{tabular}

Table 1: Taguchi design showing low (1) and high (2) values for each parameter during each experiment.

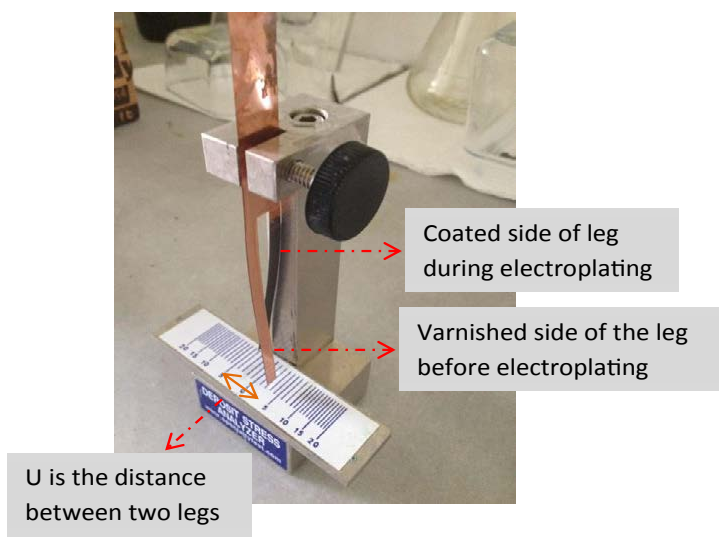

Figure 3: Bent strip test analysis setup after experiment 3 given in Table 1 showing the number of increments $(U)$.

\begin{tabular}{|c|c|}
\hline Experiment No & Response Internal Stress (MPa) \\
\hline 1 & 25.2 \\
\hline 2 & 2.3 \\
\hline 3 & 33.4 \\
\hline 4 & 14.6 \\
\hline 5 & -0.4 \\
\hline 6 & -2.1 \\
\hline 7 & -6.5 \\
\hline 8 & -4.6 \\
\hline
\end{tabular}

Table 2: Internal stress values for the experiments listed in Table 1.

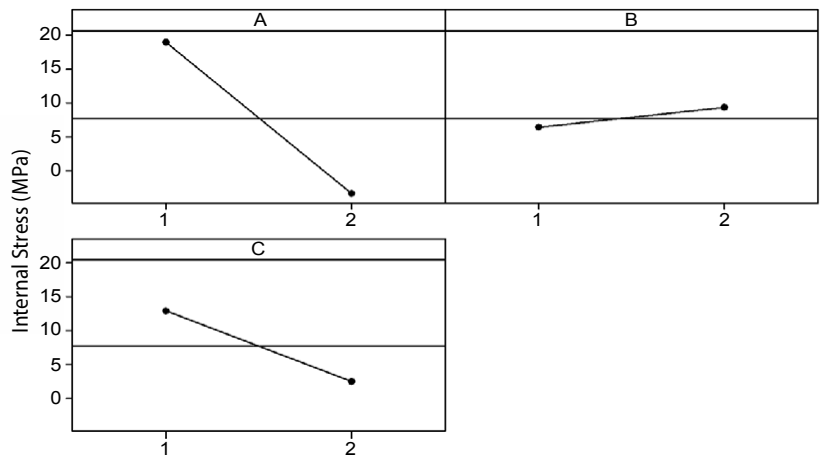

Figure 4: Internal stress (MPa) versus A: $\mathrm{MoS}_{2}$ concentration (g/l), B:Temperature $\left({ }^{\circ} \mathrm{C}\right)$, C: Thickness $(\mu \mathrm{m})$.

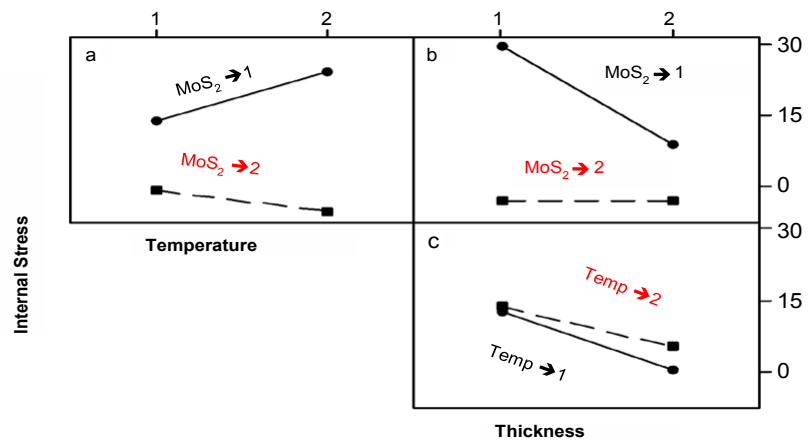

Figure 5: (a and b) Internal stress (MPa) versus interaction parameters of $\mathrm{MoS}_{2}$ concentration, temperature and thickness.

[7] that is particle incorporation in nickel deposits has decreasing effect on internal stress. Moreover, thickness effect result also agrees with the study [8]. The interaction parameters were given in Figure 5. Increasing $\mathrm{MoS}_{2}$ content transformed the temperature effect on the internal stress from increasing to decreasing (Figure 5a) and suppressed the coating thickness effect on the internal stress (Figure 5b). In addition, the regression equation for internal stress $(\mathrm{S})$ is provided by the below equation showing the amount of the effects.

\section{$\mathrm{S}=52.3-22.3 \mathrm{~A}+2.98 \mathrm{~B}-10.4 \mathrm{C}$.}

The most effective parameter is $\mathrm{MoS}_{2}$ concentration according to the regression analysis since its coefficient is 22.3. The effect of temperature can be taken as insignificant that is supported by the result of the study of Schlesinger and Paunovic due to the factor of 2.98 [9]. On the other hand, some of the studies claim that iincrease in the temperature led to decrease in the internal stress $[4,5,10]$. 
Citation: Güler ES, Karakaya I (2017) Taguchi Design of Internal Stress and Friction Measurements during Electrodeposition. J Material Sci Eng 6: 353. doi: 10.4172/2169-0022.1000353

Page 3 of 3

\section{Conclusion}

$\mathrm{MoS}_{2}$ concentration is the most important parameter that affects the internal stress. However, it must be at proper amount to show its effect on decreasing internal stress properly. Thick coatings led to decrease in the internal stress. Thickness effect on internal stress is more significant when the $\mathrm{MoS}_{2}$ concentration is low and it van be negligible when $\mathrm{MoS}_{2}$ concentration is increased to $30 \mathrm{~g} / \mathrm{l}$.

\section{References}

1. Paunovic M, Schlesinger M (2006) Fundamentals of Electrochemical Deposition New Jersey. John Wiley \& Sons.

2. Leaman FH (2007) A New Frontier for Deposit Stress Measurements. Specialty Testing and Development Company, Inc.

3. Stein B (2000) Fast and Accurate Internal Stress Determination. Proceedings of the AESF Sur/Fin.

4. Timoshkov I, Kurmashev V, Timoshkov V (2011) Electroplated Nanocomposites of High Wear Resistance for Advanced Systems Application. Advances in Nanocomposite Technology by Hashim A, Editor.

5. Wang P, Cheng YL, Zhang Z (2011) A Study on the Electrocodeposition Processes and Properties of Ni-SiC Nanocomposite Coatings. Journal of Coatings Technology and Research 8: 409.

6. Chang YC, Chang YY, Lin Cl (1998) Process Aspects of the Electrolytic Codeposition of Molybdenum Disulfide with Nickel. Electrochim. Acta 43: 315.

7. Chou MC, Ger MD, Ke ST, Huang YR, Wu ST (2005) The Ni-P-SiC Composite Produced by Electro-codeposition. Materials Chemistry and Physics 92: 146.

8. Beltowska-Lehman E, Goral A, Indyka P (2011) Electrodeposition and Characterization of $\mathrm{Ni} / \mathrm{Al}_{2} \mathrm{O}_{3}$ Nanocomposite Coatings. Archieves of Metallurgy and Materials 56: 919.

9. Schlesinger M, Paunovic M (2010) Electrodeposition of Nickel in Modern Electroplating. John Wiley \& Sons, p: 79.

10. Stein B (1996) A Practical Guide to Understanding, Measuring and Controlling Stress in Electroformed Metals. AESF Electroforming Symposium. 